\title{
The Practice and Opinions of the Applicants of a University Health Center on Multivitamin/Mineral Use, Ankara-Turkey
}

\author{
Bir Üniversitenin Sağllk Merkezine Başvuranların Multivitamin/Mineral Kullanımına İlişkin \\ Uygulama ve Görüşleri, Ankara-Türkiye
}

\author{
Duygu Ayhan Başer ${ }^{1}$, Mustafa Cankurtaran², Bahar Güçiz Doğan ${ }^{3}$
}

Received/Geliş tarihi: 26.10.2020 • Accepted/Kabul tarihi: 18.07.2021

\begin{abstract}
Aim: The aim of this study was to determine the nutritional status, knowledge on multivitamin/mineral supplements and their use among individuals who applied to an outpatient clinic and to evaluate the factors related to multivitamin/mineral preparations (MVM) use.

Subjects and Method: This descriptive study was conducted at outpatient clinics (serving for hospital staff and health sciences faculty students) between May-June 2019 with 1650 ( $\geq 18$ years of age) applicants and one out of four individuals ( $\mathrm{n}=415$ ) were asked to participate in the study. A total of 289 people accepted to participate. The data were collected via face-to-face questionnaire.

Results: Of the participants, $66.8 \%$ were women; 58.9\% were between the ages of 20-34 years; and MVM use was $36.3 \%$. Participants stated their economic status as "good" ( $p<0.001)$; physically inactive subjects ( $<<0.001)$; and current smokers ( $p=0.008$ ) were using MVMs more than the others. Almost half of them (46.0\%) thought that they had adequate and balanced diet and were using MVMs less ( $\mathrm{p}<0.001$ ). While purchasing MVMs, $61.9 \%$ of the users pay attention to price, $47.6 \%$ to the brand, $39.0 \%$ to the naturality and $32.4 \%$ to content.

Conclusion: In line with these results, in order to increase the level of awareness of people education should be provided to raise awareness on healthy nutrition and use of food supplements, at an early age, and public awareness should be ensured through mass media and social media projects.
\end{abstract}

Keywords: Multivitamin, multimineral, adult, usage status

\section{ÖZET}

Amaç: Bu çalışmanın amacı polikliniğe herhangi bir nedenle başvuran bireylerin beslenme durumlarını, multivitamin/ mineral ile ilgili bilgi durumları ve kullanımlarını belirlemek ve multivitamin/mineral (MVM) preparatı (takviyesi) kullanımıyla ilişkili faktörleri değerlendirmektir.

1. Correspondence/İletişim: Department of Family Medicine, Hacettepe University, Faculty of Medicine, Ankara, Turkey

Email: duyguayhan@outlook.com • ㄴo https://orcid.org/0000-0002-5153-2184

2. Department of Internal Medicine, Geriatrics, Hacettepe University, Faculty of Medicine, Ankara, Turkey • (1) https://orcid.org/0000-0002-8213-7515
3. Department of Public Health, Hacettepe University, Faculty of Medicine, Ankara, Turkey • (1) https://orcid.org/0000-0002-9658-2513 
Bireyler ve Yöntem: Tanımlayıcı nitelikteki bu çalışma, Mayıs-Haziran 2019 tarihleri arasında polikliniklere (hastane personeli ve Sağlık Bilimleri Fakültesi öğrencilerine hizmet veren) başvuran 1650 ( $\geq 18$ yaş) kişi ile gerçekleştirilmiş ve dört kişiden birine $(n=415)$ araştırmaya dâhil olmak isteme durumu sorulmuştur. Toplam 289 kişi katılmayı kabul etmiştir. Veriler yüz yüze uygulanan anket aracılığıyla toplanmıştır.

Bulgular: Katılımcıların \%66.8'i kadın; \%58.9’u 20-34 yaş arasında ve \%36.3’ü MVM preparatı kullanmaktadır. Katılımcılardan ekonomik durumlarını “iyi” olarak belirtenlerin ( $<<0.001$ ); fiziksel olarak inaktif olanların ( $\mathrm{p}<0.001)$; ve halen sigara içenlerin $(\mathrm{p}=0.008)$ MVM preparatlarını diğerlerinden daha fazla kullandığı saptanmıştır. MVM preparatını daha az kullananların yaklaşık yarısı (\%46.0) yeterli ve dengeli beslendiğini düşünmektedir ( $<<0.001$ ). MVM alırken kullanıcıların \%61.9’u fiyata, \%47.6’sı markaya, \%39.0’u doğallığa ve \%32.4’ü içeriğe dikkat etmektedir.

Sonuç: Bu sonuçlar doğrultusunda toplumda sağlıklı beslenme ve gerektiğinde supleman kullanımı konusunda bilinç düzeyini artırmak için erken yaşta beslenme bilincinin artırılmasına yönelik eğitimler verilmeli, kitle iletişim araçları ve sosyal medya projeleri ile kamuoyu bilinçlendirilmelidir.

Anahtar kelimeler: Multivitamin, multimineral, yetişkin, kullanma durumu

\section{INTRODUCTION}

In recent years, micronutrients (vitamins and minerals) use has increased significantly in the world as well as in Turkey, due to the change in lifestyle and nutrition culture. In developed countries, $20-30 \%$ of the population receives micronutrient supplements (1). The development of the pharmaceutical industry has increased the use of multivitamin and mineral (MVM) containing compounds (1).

When any of the vitamins are not provided into the body in sufficient amounts; disorders, deficiencies, and related clinical pathologies occur in all of the biochemical and physiological processes involved, and the functions of other micro and macro nutrients interactions (2). Body needs trace amounts of vitamins and minerals, which can be provided by consuming fruits, vegetables, legumes and cereals, and animal foods. However, for people in certain situations, vitamin and mineral supplements could be used if prescribed by a physician. These products might be indicated for pregnant women, lactating women, smokers and/or alcohol users, drug addicts, vegetarians, strict dieters, elderly people, and people who have bowel surgery, chronic disease, allergies to certain foods, congenital metabolic disease and health problems related to absorption as medical indication (3).
In Turkey, the most frequently consumed pharmaceutical products are antibiotics (19.0\%), painkillers (12.0\%), rheumatic medicines (11.0\%), and common cold medicines (8.6\%) followed by vitamins (7.3\%) (4). These products are used especially by elderly, adult women, well-educated or high-income individuals, and those who believe that good nutrition, supplemented with multivitamin/mineral products would protect health and prevent from getting ill $(4,5)$. However, misuse and overuse of vitamins does not provide prevention of diseases; while overusing can cause different health problems such as frequent and increased urination, photosensitivity, dry and cracking lips, myalgia, general malaise, itching, constipation, weight loss, appetite loss (6). Besides, vitamin use without medical indications may lead to decreased adherence to the treatment of patients in clinical pathologies, drug interactions, recurrence or prolongation of diseases, and the incidence of some undesirable effects as well as increased treatment costs $(6,7)$.

Nowadays, many people are using dietary supplements (multivitamin/minerals) to get their diets adequate, to be healthier, or to treat or prevent existing diseases by their own decisions (8-13). Multivitamin/mineral (MVM) preparations use in various groups varies 
between 9.9-70\% (8-13). To the authors' knowledge, no study was conducted up to date on MVM related knowledge and use in hospital staff and health sciences faculty students, who spend most of their daily life in various health facilities and who may have easier access to medical information. The aim of this study was to determine the nutritional status, multivitamin/ mineral knowledge, and use of individuals (hospital staff and students) who applied to a primary care outpatient clinic for any reason and to evaluate the factors related to MVM use.

\section{SUBJECTS AND METHOD}

This descriptive study was conducted at Hacettepe University Health Center (primary care) outpatient clinics between May 2019 and June 2019. These outpatient clinics meet the health needs of Hacettepe University staff and students. Within this period, 1650 subjects were admitted to the center ( $\geq 18$ years of age), and systematically randomly one out of four individuals $(n=415)$ were asked to participate the study. A total of 289 people (69.6\%) accepted to participate.

The Non-Interventional Clinical Research Ethics Board approval (number: GO 19/470, date: 07/05/2019) and oral informed consents were obtained, and researchers administered the questionnaire.

The data were collected via structured, pre-tested, face-to-face implemented questionnaire prepared by the researchers using the related literature. The questionnaire consisted of 37 questions which were pre-tested and validated previously, covering demographic data (age, sex, education status, marital status, working status, economic status, place of residence), medical history (body mass index-BMI, presence of diagnosed disease, drug use status, selfassessment of health status as good or moderate or bad), general health status, nutritional status (breakfast/lunch/dinner consumption frequency), healthy life behaviors (self-assessment of adequate and balanced nutrition status, regular physical activity status, smoking status), multivitamin/mineral use (non-mono-vitamin), knowledge, and opinions.
Body mass index (BMI) values of the individuals was calculated by using the formula: BMI $\left(\mathrm{kg} / \mathrm{m}^{2}\right)=$ Body weight $(\mathrm{kg}) /$ Height $\left(\mathrm{m}^{2}\right)$. Accordingly, normal-weight for adults is defined as a BMI between $18.5-24.9 \mathrm{~kg} / \mathrm{m}^{2}$, underweight as a BMI less than $18.5 \mathrm{~kg} / \mathrm{m}^{2}$, overweight as a BMI $25.0-29.9 \mathrm{~kg} / \mathrm{m}^{2}$, and obesity as a BMI of 30.0 $\mathrm{kg} / \mathrm{m}^{2}$ or greater. Self-reported body weight and height values were used. The interviews were conducted in the outpatient room after the applicant's medical needs were met. The interviews lasted around 20-25 minutes.

\section{Statistical Evaluation of Data}

Statistical analyses were carried out by using SPSS-23 Statistical Package Program for Windows. Qualitative variables were presented as frequencies and percent distributions, and location and dispersion statistics (mean, standard deviation, median, 1st-3rd quarters, min-max) for continuous variables were presented. Chi-square/Fisher's exact /exact chi-square tests were used to evaluate the observed differences in bivariate analyses. The level of error was accepted as $\alpha=0.05$.

\section{RESULTS}

Of the participants, $66.8 \%$ were women; $58.9 \%$ between the ages of $20-34(\mid \operatorname{bar}\{x\} \pm S D=28.6 \pm 11.5$, $\min =18-\max =62$ ) years; $58.5 \%$ were senior high school graduates; $71.3 \%$ were never married; $42.6 \%$ were in normal BMI ( $\mathrm{b}$ ar $\{\mathrm{x}\} \pm \mathrm{SD}=25.778 \pm 5.014$ ( $\mathrm{min}=16.59$ $\max =39.83) \mathrm{kg} / \mathrm{m}^{2}$ and $58.8 \%$ were university student at the time of the study. Out of total, $55.7 \%$ of the participants had a disease/condition diagnosed by a physician; the most common three conditions were vitamin D deficiency (41.0\%), vitamin $\mathrm{B}_{12}$ deficiency (27.3\%), and anemia (24.2\%). MVM use was 36.3\% among the participants. There was no statistically significant relationship between MVM use and gender, age, educational status, marital status, working status, place of living, diagnosed disease status, BMI groups $(p>0.05)$. It was observed that participants stated their economic status as "good" ( $<<0.001)$; physically inactive $(p<0.001)$; and current smoker $(p=0.008)$ were using MVM more than the others (Table 1). 
Table 1. Distribution of MVM use by some characteristics of participants*

\begin{tabular}{|c|c|c|c|c|c|c|c|}
\hline \multirow{3}{*}{ Characteristics } & \multicolumn{6}{|c|}{ Use of MVM } & \multirow{3}{*}{$\mathbf{p}$} \\
\hline & \multicolumn{2}{|c|}{ Total $(n=289)$} & \multicolumn{2}{|c|}{ Yes $(n=105)$} & \multicolumn{2}{|c|}{ No $(n=174)$} & \\
\hline & $\mathrm{n}$ & $\% *$ & $\mathrm{n}$ & $\%$ & $\mathbf{n}$ & $\%$ & \\
\hline \multicolumn{8}{|l|}{ Sex } \\
\hline Female & 193 & 66.8 & 76 & 39.4 & 117 & 60.6 & \multirow{2}{*}{0.060} \\
\hline Male & 96 & 33.2 & 27 & 28.1 & 69 & 71.9 & \\
\hline \multicolumn{8}{|l|}{ Age (year) } \\
\hline $20 \geq$ & 74 & 25.6 & 28 & 37.8 & 46 & 62.2 & \multirow{3}{*}{0.382} \\
\hline 21-35 & 147 & 50.9 & 47 & 32 & 100 & 68 & \\
\hline $36 \leq$ & 68 & 23.5 & 28 & 41.2 & 40 & 58.8 & \\
\hline \multicolumn{8}{|l|}{ Educational Status } \\
\hline Primary School and less & 18 & 6.2 & 8 & 44.4 & 10 & 55.6 & \multirow{4}{*}{0.400} \\
\hline Senior High School & 169 & 58.5 & 57 & 33.7 & 112 & 66.3 & \\
\hline University/College & 91 & 31.5 & 36 & 39.6 & 55 & 60.4 & \\
\hline Postgraduate & 11 & 3.8 & 2 & 18.2 & 9 & 71.8 & \\
\hline \multicolumn{8}{|l|}{ Marital status } \\
\hline Never married & 206 & 71.3 & 71 & 34.5 & 135 & 65.5 & \multirow{2}{*}{0.511} \\
\hline Married & 83 & 28.7 & 32 & 38.6 & 51 & 61.4 & \\
\hline \multicolumn{8}{|l|}{ Working status } \\
\hline Working & 118 & 40.8 & 47 & 39.8 & 71 & 60.2 & \multirow{2}{*}{0.217} \\
\hline Not working** & 171 & 59.2 & 56 & 32.7 & 115 & 67.3 & \\
\hline \multicolumn{8}{|l|}{ Economic status } \\
\hline High income & 55 & 19.0 & 40 & 72.7 & 15 & 27.3 & \multirow{3}{*}{$<0.001^{* * *}$} \\
\hline Middle income & 217 & 75.1 & 60 & 27.6 & 157 & 72.4 & \\
\hline Low income & 17 & 5.9 & 3 & 17.6 & 14 & 82.4 & \\
\hline \multicolumn{8}{|l|}{ Residence } \\
\hline Home & 208 & 72.0 & 78 & 37.5 & 130 & 62.5 & \multirow{2}{*}{0.373} \\
\hline Dormitory & 81 & 28.0 & 25 & 31.6 & 54 & 68.4 & \\
\hline \multicolumn{8}{|l|}{ Disease status } \\
\hline Yes & 161 & 55.7 & 55 & 34.4 & 106 & 65.6 & \multirow{2}{*}{0.689} \\
\hline No & 128 & 44.3 & 44 & 36.6 & 84 & 63.4 & \\
\hline \multicolumn{8}{|l|}{ BMI (kg/m²) } \\
\hline Underweight & 15 & 5.2 & 4 & 26.7 & 11 & 73.3 & \multirow{4}{*}{0.464} \\
\hline Normal & 123 & 42.6 & 50 & 40.7 & 73 & 59.3 & \\
\hline Overweight & 85 & 29.4 & 28 & 32.9 & 57 & 67.1 & \\
\hline Obese & 66 & 22.8 & 21 & 31.8 & 45 & 68.2 & \\
\hline Regular Physical Activi & & & & & & & \\
\hline Yes & 104 & 64.0 & 14 & 13.5 & 90 & 86.5 & \\
\hline No & 185 & 36.0 & 89 & 48.1 & 96 & 51.9 & $<0.001 * * *$ \\
\hline Smoking status & & & & & & & \\
\hline Non-smoker & 172 & 59.5 & 47 & 27.3 & 125 & 72.7 & \\
\hline Ex-smoker & 19 & 6.6 & 8 & 42.1 & 11 & 57.9 & $0.008^{* * *}$ \\
\hline Smoker & 98 & 33.9 & 48 & 48.9 & 50 & 51.1 & \\
\hline
\end{tabular}

* Difference between groups according to MMP usage, Chi-square $\left(x^{2}\right)$ test

${ }^{* *}$ Column percentages; others are row percentages.

${ }^{* * *} p<0.05$

****58.8\% was student. 
Of the participants, $44.6 \%$ evaluated their health status as "good"; $6.6 \%(n=19)$ evaluated their health status as bad. Almost half of them (46.0\%) thought that they had adequate and balanced diet. The people who thought that their health status was "good" were using MVM less $(\mathrm{p}<0.001)$ as well as the people who had adequate and balanced diet $(\mathrm{p}<0.001)$. Among MVM users ( $\mathrm{n}=105), 51.4 \%(\mathrm{n}=54)$ were using it less than 30 days; $24.8 \%(n=26)$ stated that they were using it daily (Figure 1). The frequency of use of MVM are shown in Figure 1.

The most common reasons for using MVM were malaise, suggestion, frequent infections, lack of concentration $(68.6 \%, 37.1 \%, 33.3 \%, 30.5 \%$, respectively) (Table 2). Almost three-fourth (71.4\%) of the participants obtained the supplements from pharmacy, 41.9\% $(n=44)$ from internet and 15.2\% ( $n=$ 16) from the sports centers.

While obtaining MVM, $61.9 \%$ of the users pay attention to price, $47.6 \%$ to the brand, $39 \%(n=41)$ to the naturality (presence of additive) and $32.4 \%(n=34)$ to the content (i.e. coenzyme Q-10, vitamin C and ginseng).

Among MVM users, 95.2\% did not experience any side effects related to these supplements; only three people reported side-effects (one nausea, one itching, and one nausea and vomiting).

Of the users, $96.2 \%$ stated that they would recommend MVM use to others as well as believing the effectiveness and necessity of use. However, non-users would not recommend MVM use to others $(p<0.001)$.

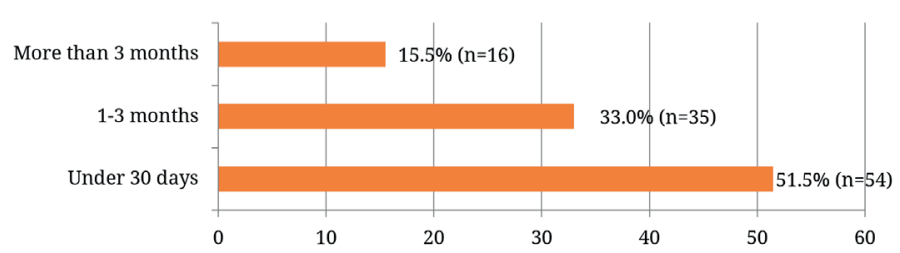

Figure 1. The duration of use of MMP

Table 2. Reasons for using MVM

\begin{tabular}{lcc}
\hline Reasons for using & $\mathbf{n}$ & $\mathbf{\%}^{*}$ \\
\hline Fatigue/tiredness & 72 & 68.6 \\
Frequent infections & 35 & 33.3 \\
Recommendation** & 34 & 32.3 \\
Lack of concentration & 32 & 30.5 \\
Irregular feeding / food supplement & 18 & 17.1 \\
Others*** & 16 & 15.3 \\
Vitamin deficiency & 14 & 13.3 \\
Weight loss & 3 & 2.9 \\
Anemia & 2 & 1.9 \\
\hline${ }^{*}$ More than one answer; the percentages counted from the total separately. \\
**Recommended by physician, dietician, physiotherapist, pharmacist at any \\
time \\
*** Anemia, own decision
\end{tabular}

Table 3. Distribution of the participants according to their thoughts about MVM use

\begin{tabular}{|c|c|c|c|c|c|c|c|}
\hline & \multicolumn{6}{|c|}{ Use of MVM } & \multirow{3}{*}{$\mathbf{p}^{*}$} \\
\hline & \multicolumn{2}{|c|}{ Total $(n=289)$} & \multicolumn{2}{|c|}{ Yes $(n=105)$} & \multicolumn{2}{|c|}{ No $(n=184)$} & \\
\hline & $\mathbf{n}$ & $\% * *$ & $\mathbf{n}$ & $\% * *$ & $\mathbf{n}$ & $\% * *$ & \\
\hline \multicolumn{8}{|c|}{ Recommending a MVM to others } \\
\hline Yes & 113 & 39.1 & 101 & 96.2 & 12 & 6.5 & \multirow{2}{*}{$<0.001^{* * *}$} \\
\hline No & 176 & 60.9 & 4 & 3.8 & 172 & 94.5 & \\
\hline \multicolumn{8}{|c|}{ Believing the effectiveness of MVM } \\
\hline Yes & 113 & 39.1 & 101 & 96.2 & 12 & 6.5 & \multirow{2}{*}{$<0.001^{* * *}$} \\
\hline No & 176 & 60.9 & 4 & 3.8 & 172 & 94.5 & \\
\hline \multicolumn{8}{|c|}{ Believing the necessity of using MVM in case of regular nutrition } \\
\hline Yes & 98 & 33.9 & 90 & 85.7 & 8 & 4.3 & \multirow{2}{*}{$0.001 * * *$} \\
\hline No & 191 & 66.1 & 15 & 14.3 & 176 & 95.7 & \\
\hline
\end{tabular}




\section{DISCUSSION}

Multivitamin/mineral supplement (MVM) use shows an increasing trend among people; however, MVM are used without medical supervision. In the European Union (EU), food supplements are regulated as foods. Harmonized legislation regulates the vitamins and minerals, and the substances used as their sources, which can be used in the manufacturing of food supplements (14). Despite their beneficial effects, MVM cannot replace a balanced diet that includes essential nutrients. According to Turkish Food Codex Communique on supplementary foods, for individuals aged 11 and over, legally it is recommended that vitamins and minerals should be at least $15 \%$ of the nutritional reference value in supplements containing vitamins and minerals and should be included within the maximum limits, and should be half of this value for children aged 4-10 (15). MVM use varies between 9.9-70\%, and these results reveal the uncontrolled and out of indication use of MVM (8-13). The findings of the current study revealed a similar proportion (36.3\%) of MVM use in the study group.

According to the results of the National Health and Nutrition Research III (NHANES) (1999-2000) conducted periodically in the United States, 52.0\% of adults reported using a dietary supplement in the past month; 35.0\% took a MVM (16). In National Health Interview Survey (NHIS) (2000), 52.7\% of the participants reported using a MVM (17). In NHANES (2017-2018), 57.6\% of adults aged 20 and over reported using any dietary supplement in the past 30 days (7). Bailey et al (18) reported that $45.0 \%$ of adult supplement users taking $>1$ supplement in the past 30 days. In a study conducted in 2014 on 120 people in India, it was determined that $68.3 \%$ of them used MVM (19). In another study reported from United Arab Emirates, $46.5 \%$ of 319 medical school students were using MVM (20). The studies show that food supplements are widely used in our country as in the world. In most recent three studies conducted in Turkey on university students, parents, and a group of adults) MVM use was found between 13.2-67.8\% $(5,11,12)$. According to the Turkish Nutrition and
Health Survey 2017, 6.1\% of individuals aged 15-18 were using MVM supplements. These figures were $9.7 \%$ for $19-64$ years, $14.3 \%$ for 65 of age and over; overall proportion of MVM use among 15 age and over individuals was $9.9 \%$ supplements (13).

Results of this study indicates that high income was associated with MVM use. This finding could seem reasonable for Turkey since these supplements are not covered by the Governmental Health Insurance System, and the fare should be paid by the individuals (4). In a study conducted with U.S. adults, in accordance with study, the MVM use was higher among those with private health coverage and people who tended to have higher incomes (16). Another statistically significant related factor to MVM use was self-reported health status; participants who had a self-reported good health status use MVM higher than others, similar with U.S. study $(20,21)$. This reflects the relationship between people's perception of health and the need for supportive nutrients that may increase in parallel. Because people can evaluate their MVM supplements as extra energy intake or immune supplements, this may be why users feel better than others.

Of the participants, $63.5 \%$ who thinks that they have not adequate and balanced diet were using MVM, on the contrary, $4.5 \%$ of the participants who have sufficient and balanced diet was also using a MVM. Adequate and balanced nutrition perception is a relative thought and could be affected by many factors. A full stomach could be a criterion for sufficient and balanced nutrition for a person while the quality and content of the food consumed for another. The idea of supplementing the diet with micronutrients might be a necessity for those who think that they do not have enough and balanced diet. The primary reasons stated such as nutritional deficiency and health protection for MVM intake in other studies conducted support this finding $(12,18,19)$.

Similar to previous studies, use of MVM in adults was associated with good health characteristics, such as 
regular physical activity, abstinence from smoking (18,21-23) It may be that individuals who have a healthy life behavior have a better perception of their own health than others, which might explain their use of MVM less.

In Coşkun et al's study (12), 25\% of participants reported that they regularly use vitamins every day similar to our study (24.8\%). To the authors' knowledge, there is no cross-sectional study similar to our study except Coşkun et al's study related to daily MVM use.

The most common reasons stated by the participants for using MVM are malaise, suggestion, frequent infection, and lack of concentration, respectively. In many studies in the literature, the main reasons for the consumers' use of vitamins are stated to feel tired and think they have an unbalanced diet $(12,19,20)$. It could be said that people feel tired due to their intense daily life and working conditions, illness, stress, and not being able to pay attention to their diet in daily rush. It could be said that these conditions might lead people to use MVM in order to increase their quality of life. In this study, prevention of frequent infections is also among the causes of MVM use. In a study, which questioned the MVM use of both parents and their children, parents stated that they frequently use MVM to strengthen the immune system either for themselves or their children, and to protect themselves against cancer (5). One of the most frequently considered ingredients is vitamin $\mathrm{C}$, which strengthens this opinion.

In total, $59.0 \%$ of MVM users had started to use on the recommendation of health personal such as physicians, dietitians, physiotherapists, $28.2 \%$ of pharmacists, and $12.8 \%$ via internet. On the contrary, it was stated that MVM users had obeyed physician or internet recommendations only $(12,19)$. In Turkey, MVM have been sold under the permission of the Ministry of Agriculture and Forestry, and the health insurance system does not cover the payment. This situation increases the uncontrolled and unstable use of that sort of products. Moreover, especially internet advertisements have a great impact on using MVM, also using these supplements without counseling a physician and not containing the recommended levels, and especially for individuals using medications and who are pregnant. Since there might be some side effects, using of these supplements above the recommended maximum levels. In this regard, audits and warnings by the Ministry of Health and the Ministry of Agriculture and Forestry can reduce the uncontrolled use of MVMs. Public awareness should be increased by the health professionals and internet selling should be avoided.

In this study, the first three points participants stated while purchasing a MVM supplement were price (61.9\%), brand (47.6\%), and naturality (39.0\%), while in another study conducted in Turkey, price was the least stated feature (12). This might be due to the participants of the current study who were mainly students. Besides, $32.4 \%$ of the participants stated that they pay attention to the content; Coenzyme Q, Vitamin $\mathrm{C}$ and Ginseng were the most preferred ingredients. Vitamin C may be chosen due to its immune system strengthening effect, and Ginseng and Coenzyme Q are particularly prominent in advertisements that may explain the reason the preference. This result reveals once again the effect of advertisements on the use of MVM.

Considering the opinions of the participants, more than one-third of the participants (39.1\%) stated that they have believed on the effectiveness of MVM and would recommend the use of MVM to the others. In a study reported from United Arab Emirates , 74.8\% believed on the effect of MVM, and $61.3 \%$ stated that they would recommend it (16). In the study it was found that, $96.2 \%$ of MVM users stated that they will recommend MVM to the others and believed in their efficacy, while only $6.5 \%$ of MVM was non-users. That is, if someone uses MVM and experienced the positive effects or believes that there would be some positive effect in the future, he/she recommends to the others. It was seen that $85.7 \%$ of those who use MVM have positive thoughts that it may be necessary to use MVM even in regular nutrition. This belief might be sourced 
from the advertisements presents these preparations as energizing supplements. Moreover, most of the people might not have the knowledge that "a healthy individual will not need MVM in case of adequate and balanced nutrition" (1,2), and healthcare professionals might neglect to give counseling on this issue to their clients. Public training efforts and public campaigns on this subject could be helpful to reverse this perception.

In line with these results, in order to increase the level of awareness of people on these issues, education should be provided to raise awareness of nutrition beginning at an early age, and public awareness should be made through the mass media, and social media projects. Health personnel should explain indications of MVM and its side effects that may occur in case of misuse when needed. Within the framework of rational medication use, more training should be given to physicians and pharmacists.

\section{LIMITATIONS}

Since the sample of this study was not representative, the findings could not be generated for the universe. The findings are representative of the study sample and caution is necessary when extrapolating the data for the general public. We cannot completely rule out the potential for self-selection bias. Furthermore, given the descriptive nature of the data we cannot evaluate causality which related with MVM use.

Author contributions: Study design: DAB, BGD; Data collection: $D A B, B G D, M C$; Data analysis: $D A B, B G D$; Draft preparation: $D A B, B G D, M C$; Critical review for content: $B G D$; Final approval of the version to be published: $D A B, B G D$.

Ethics approval: Ethical Approval was obtained from Hacettepe University Non-Interventional Clinical Research Ethics Board with the date 07/05/2019 and decision number GO 19/470.

Conflict of interest: The authors declare that they have no conflict of interest.

Acknowledgements: There is no acknowledgement.

\section{REFERENCES}

1. Orhon FŞ, Gülnar SB. Vitamin ve mineral kullanımının doğru ve yanlış endikasyonları. Türkiye Klinikleri Pediatrik Bilimler Dergisi. 2006;2:161-5.

2. Öz SG, Kılıcarslan A. Vitaminlerin yaşamımızdaki yeri nedir, ne olmalıdır? İç Hastalıkları Dergisi. 2012;19:13943.

3. Erden BF, Tanyeri P. Ülkemizde vitamin ve mineral eklentilerinin akılcı kullanımı. STED. 2004;13:411-4.

4. Türkiye İlaç ve Tıbbi Cihaz Kurumu. Akılcı İlaç Kullanımı. Erişim: http://www.akilciilac.gov.tr Erişim tarihi: 20 Nisan 2020.

5. Bülbül $S$, Sürücü $M$, Aşık G. Vitamin kullanım alışkanlıkları ve etkileyen faktörler. Çocuk Sağlığı ve Hastalıkları Dergisi. 2014;57:241-5.

6. Wooltorton E. Too much of a good thing? Toxic effects of vitamin and mineral supplements. CMAJ. 2003;169(1):478.

7. Mishra S, Stierman B, Gahche JJ, Potischman N. Dietary Supplement Use Among Adults: United States, 20172018. NCHS Data Brief. 2021;(399):1-8.

8. Bailey RL, Gahche JJ, Lentino CV, Dwyer JT, Engel JS, Thomas PR, et al. Dietary supplement use in the United States, 2003-2006. The Journal of Nutrition. 2011;141(2):261-6.

9. Chen SY, Lin JR, Chen TH, Guo SG, Kao MD, Pan WH. Dietary supplements usage among elderly Taiwanese during 2005-2008. Asia Pac J Clin Nutr. 2011;0(2):327.

10. Yolcu H. MÜSİAD Sağllk Sektör Kurulu Raporu [Internet]. İstanbul: 2012. [cited 2020 Apr 20] Available from: $\quad$ http://www.musiad.org.tr/F/Root\%20/Pdf/ Ara\%C5\%9Ft\%C4\%B1rma\%20Raporlar\%C4\%B1/ Sekt\%C3\%B6r\%20Raporlar\%C4\%B1/Saglik_Sektor_ Kurulu_Raporu_2012.pdf.

11. Keser A, Yabancı N, Öztürk ME. Üniversite öğrencilerinin vitamin ve mineral desteği kullanım durumları. Sağlık Bilimleri Dergisi. 2014;(23):108-13.

12. Coşkun F, Turhan $H$. İstanbul'da vitamin kullanım alışkanlıkları ve bu alışkanlıkları etkileyen faktörler üzerine bir araştırma. Marmara Eczacılık Dergisi. 2010;(14):21-8.

13. Turkey Nutrition and Health Survey (TBSA), T.C. Sağllk Bakanlığı Halk Sağlığı Genel Müdürlüğü, Yayın No:1132, Ankara, 2019.

14. EFSA-European Food Safety Authority. Food supplements. 2021. Available at: https://www.efsa. europa.eu/en/topics/topic/food-supplements Accessed Apr 20, 2021. 
15. Türk Gıda Kodeksi Takviye Edici Gıdalar Tebliği, Tebliğ No (2013/49) Resmî Gazete:16.08.2013-28737. Erişim: https:// www.resmigazete.gov.tr/eskiler/2013/08/20130816-16. htm Erişim tarihi: 20 Temmuz 2021.

16. Radimer K, Bindewald B, Hughes J, Ervin B, Swanson C, Picciano MF. Dietary supplement use by US adults: Data from the National Health and Nutrition Examination Survey 1999-2000. Am J Epidemiol. 2004;160:339-49.

17. Fennell D. Determinants of supplement usage. Prev Med. 2004;39:932-9.

18. Bailey RL, Gahche JJ, Miller PE, Thomas PR, Dwyer JT. Why US adults use dietary supplements. JAMA Intern Med. 2013;173:355-61.

19. Sekhri K, Kaur K. Public knowledge, use and attitude toward multivitamin supplementation: A crosssectional study among general public. Int J App Basic Med Res. 2014;4:2.
20. Rosalia R, Panjwani S, Ali AA, Hameed Al Hayali MM, Alahmad AM, Shirwaikar A, et al. A Cross Sectional Survey on the Knowledge and Attitude towards the Use of Multivitamin Products among the Students of a Medical University in the U.A.E. Journal of Applied Pharmaceutical Science. 2017;7(8):201-8.

21. Cowan AE, Jun S, Gahche JJ, Tooze JA, Dwyer JT, EicherMiller HA, et al. Dietary Supplement Use Differs by Socioeconomic and Health-Related Characteristics among U.S. Adults, NHANES 2011-2014. Nutrients. 2018;10(8):1114.

22. Gahche JJ, Bailey RL, Potischman N, Dwyer JT. Dietary supplement use was very high among older adults in the United States in 2011-2014. J Nutr. 2017;147:1968-76.

23. Rock CL. Multivitamin-multimineral supplements: Who uses them? Am J Clin Nutr. 2007;85:277-9. 